\title{
EFEKTIVITAS BIOADSORBEN KULTT KEDELAI (Glycine Max) UNTUK MENURUNKAN KADAR BESI (Fe) DALAM AIR
}

Alfatur Hari Wicaksono, Ferry Kriswandana, Marlik

Jurusan Kesehatan Lingkungan Poltekkes Kemenkes Surabaya

Email : marlik2503@gmail.com

\begin{abstract}
ABSTRAK
Kandungan besi $(\mathrm{Fe})$ yang berlebih dalam air adalah salah satu permasalahan yang diakibatkan oleh pencemaran lingkungan air. Berdasarkan Peraturan Menteri Kesehatan Nomor 32 Tahun 2017 standar baku mutu kandungan besi (Fe) dalam air adalah 1mg/l, jika melebihi ambang batas yang telah ditetapkan akan berdampak pada memburuknya kualitas air dan menimbulkan gangguan yang merugikan. Kandungan besi (Fe) terlarut dalam air yang berlebih, juga dapat menimbulkan warna, bau, rasa pada air. Sehingga diperlukan pengolahan untuk menurunkan kandungan besi (fe) pada air.Salah satu metode yang saat ini masih sering digunakan dan efektif untuk mengurangi pencemaran terutama pencemaran logam adalah metode adsorpsi. Bioadsorben adalah arang aktif yang berasal dari alam (bagian dari tumbuhan), sehingga inovasi untuk memanfaatkan limbah dari tumbuhan sebagai bioadsorben perlu dilakukan. Pada penelitian ini, kulit kedelai dapat dijadikan bahan bioadsorben untuk menurunkan kadar besi (fe) dalam air.

Hasil penelitian pada kadar air memenuhi standar dari SNI 06-3730-1995 tentang arang aktif teknis dengan nilai (4.16\%) sedangkan untuk parameter kadar abu tidak memenuhi syarat yaitu (17.22\%). Presentase penurunan besi paling bagus terjadi pada dosis $10 \mathrm{gr} / \mathrm{l}$ dimana terjadi rata-rata penurunan besi sebesar $4.08 \mathrm{mg} / \mathrm{l}(98 \%)$ sedangkan dosis optimum yang didapatkan dari analisis probit adalah $3.205 \mathrm{gr} / \mathrm{l}$ dimana terjadi penurunan kadar besi sebesar $(80 \%)$ hingga memenuhi standar Permenkes nomor 32 th 2017.

Untuk kadar abu yang belum memenuhi standar SNI 06-3730-1995 tentang arang aktif teknis daat ditingkatkan dengan cara meningkatkan kualitas arang aktif melalui peningkatan suhu karbonisasi dan menggunakan aktivator lain untuk membuat bioadsorben kulit kedelai.
\end{abstract}

Kata Kunci : Air, Bioadsorben, Kulit Kedelai (Glycine Max), Besi (Fe).

\section{PENDAHULUAN}

Kualitas air yang memburuk dapat menurunkan segala aspek yang ada, seperti daya guna, hasil guna, produktivitas daya tampung dan daya dukung dari sumber air dan akan menurunkan kekayaan sumber daya alam yang menjadi kebutuhan dan modal pembangunan (Perda Jatim, 2008). Mengingat sangat pentingnya peran air dalam kehidupan manusia, tumbuhan hingga hewan, perlu adanya peraturan tegas yang juga harus diimplementasikan dengan baik.

Berdasarkan Peraturan Menteri Kesehatan Nomor 32 tahun 2017 tentang Standar Baku Mutu Kesehatan Lingkungan dan Persyaratan Kesehatan Air untuk Keperluan Higiene Sanitasi, Kolam Renang, Solus Per Aqua, dan Pemandian Umum parameter besi (Fe) dalam standar baku mutu adalah $1 \mathrm{mg} / \mathrm{l}$, jika kandungan besi ( $\mathrm{Fe}$ ) melebihi nilai baku mutu yang telah ditetapkan dapat menimbulkan pencemaran khususnya lingkungan air. Memburuknya kualitas air menimbulkan gangguan yang merugikan, baju, wastafel dan kloset menjadi kotor, sifat korosif terhadap pipa terutam pipa GI sehingga mengendap pada saluran pipa yang kemudian mengakibatkan kebuntuan pada pipa (clogging). Kandungan besi (Fe) terlarut dalam air yang berlebih, juga dapat menimbulkan warna, bau, rasa pada air. (Arief 2016)

Salah satu metode yang saat ini masih sering digunakan dan efektif untuk mengurangi pencemaran terutama pencemaran logam berat adalah metode adsorpsi. Karbon aktif, Silika aktif, zeolit adalah contoh bahan adsorben yang umumnya digunakan. karbon aktif dibuat 
dengan cara destilasi kering lalu diaktivasi dengan zat tertentu. Pada pembuatan arang aktif bahan yang biasa digunakan adalah batubara dikarenakan kandungan karbon dalam batubara cukup tinggi (Ghafarunnisa et al. 2017). Akan tetapi batubara adalah sumber daya alam yang tidak continyu dan relatif mahal, jika digunakan terus-menerus batu bara akan habis. Banyak penelitian yang telah membuktikan bahwa bahan dari alam dapat menggantikan batu bara sebagai bahan baku pembuatan arang aktif, mulai dari kulit durian, batok kelapa, kulit pisang kepok hingga kulit kedelai (Glycine max), dan berbagai macam jenis kayu dapat dimanfaatkan untuk pembuatan arang aktif yang berasal dari alam (bioadsorben).

Krisis kedelai menunjukkan masih adanya ketergantungan pemenuhan pada impor sehingga pada tahun 2018 ini Pemerintah Provinsi Jawa Timur akan memperluas lahan tanaman kedelai dari 200 ribu hektar, akan ditambah menjadi 250 ribu hektar (Duta.co 2018 diakses tanggal 25 Oktober pukul 13.52 WIB). Perluasan lahan penanaman kedelai diperluas dikarenakan poduksi lokal 399 ribu ton tidak mampu memenuhi kebutuhan konsumsi kedelai yang menyentuh angka 448 ribu ton di tahun 2018, sehingga kekurangan tersebut dipenuhi dengan impor kedelai sebanyak 48 ribu ton (Pojokpitu.com 2018 diakses tanggal 25 Oktober pukul 14.13 WIB). Dengan adanya program Pemerintah Provinsi Jawa Timur yang bertujuan untuk meningkatkan produksi / lahan tanam kedelai akan diikuti meningkatnya kulit kedelai.

Tujuan dari penelitian ini yaitu menganalisis efektivitas bioadsorben kulit kedelai (Glycine Max) dalam menurunkan kadar besi (Fe) dalam air.

\section{METODE PENELITIAN}

Penelitian ini menggunakan Rancangan Eksperimen Ulang (PretestPosttest Control Group Design). Subyek penelitian dibagi secara random kedalam kelompok perlakuan ( $\mathrm{X}$ ) dan kelompok kontrol yang tidak diberi perlakuan (-). Pengukuran atau Observasi dilakukan sebelum dan sesudah diberikan perlakuan. (Haidah and Irmawartini 2018).

Kulit kedelai (Glycine Max) sebagai bioadsorben berukuran 100 mesh dengan variasi dosis $2 \mathrm{gr} / \mathrm{l}, 6 \mathrm{gr} / \mathrm{l}, 10 \mathrm{gr} / \mathrm{l}$, dan 0 gr/l (kontrol) yang dihitung kadar air dan kadar abunya. Penelitian ini menggunakan $12.000 \mathrm{ml}$ air aquades yang dicampurkan dengan garam besi sebanyak 50,04 mg, sehingga didapatkan kadar besi dalam air 4,17 mg/l. Dosis bioadsorben dicampurkan ke air baku kemudian dilakukan jartest selama 90 menit dan 30 menit pendiaman. Masing masing dosis direplikasi sebanyak 6 kali untuk pemeriksaan kadar besi (Fe), guna mendapatkan hasil yang akurat. Kadar besi ( $\mathrm{Fe}$ ) pada masing masing dosis diteliti selain itu juga mengukur kadar air dan kadar abu. Analisis data yang digunakan dalam penelitian ini adalah uji One Way Annova dan dilanjutkan dengan uji Probit. 


\section{HASIL}

\section{Pemeriksaan kadar air dan kadar abu bioadsorben kulit kedelai}

Tabel 1

MUTU ARANG AKTIF KULIT KEDELAI

\begin{tabular}{cccc}
\hline No & $\begin{array}{c}\text { Jenis } \\
\text { Parameter }\end{array}$ & $\begin{array}{c}\text { Hasil Analisa } \\
\text { Laboratrium (\%) }\end{array}$ & Persyaratan (\%) \\
\hline 1 & Kadar Air & 4.16 & Maks. 15 \\
\hline 2 & Kadar Abu & 17.22 & Maks. 10 \\
\hline
\end{tabular}

Berdasarkan tabel 1 didapatkan hasil perbandingan mutu arang aktif (Kadar Air dan Kadar Abu) antara hasil pemeriksaan laboratoriun dengan SNI 06 37301995 sehingga dapat ditarik kesimpulan bahwa Kadar Air (4.16\%) arang aktif yang terbuat dari kulit kedelai Memenuhi Persyaratan di SNI 063730 1995 (Maksimal 15\%) dan untuk Kadar Abu (17.22\%) arang aktif yang terbuat dari kulit kedelai Tidak Memenuhi Persyaratan di SNI $06 \quad 3730 \quad 1995$ (Maksimal $10 \%$ ).

Pembuatan arang aktif dari bahan dasar kulit kedelai meliputi; pengumpulan kulit kedelai, pembersihan kulit kedelai menggunakan air, penjemuran kulit kedelai. Setelah kulit kedelai dijemur dengan panas matahari, kulit tersebut dihaluskan dan disaringan dengan mesh ukuran 100, proses pembuatan berlanjut di proses dehidrasi menggunakan oven dengan suhu $105^{\circ} \mathrm{C}$ selama 1 jam. Setelah proses (karbonasi) menggunakan furnace selama 1 jam dengan suhu $275{ }^{\circ} \mathrm{C}$, kemudian proses terakhir dari pembuatan arang aktif ini adalah proses aktivasi dengan asam kuat (KOH 5\%) selama 1x24 jam.

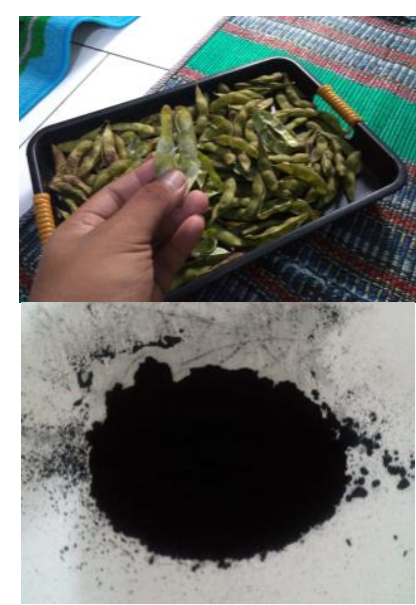

Gambar 1.

Kulit jedelai yang telah menjadi bioadsorben

Pengukuran kadar besi (Fe) pada air baku sebelum dan sesudah penambahan bioadsorben kulit kedelai.

Tabel 2

HASIL PEMERIKSAAN

KADAR BESI (FE) PADA AIR BAKU

\begin{tabular}{|c|c|c|c|c|c|c|c|c|c|c|}
\hline \multirow[t]{2}{*}{$\begin{array}{l}\text { Dosis } \\
(\mathrm{gr} / \mathrm{l})\end{array}$} & \multicolumn{6}{|c|}{$\begin{array}{c}\text { Kadar Besi (Fe) dalam Air } \\
\text { Baku pada Replikasi Ke- } \\
\text { (ppm) }\end{array}$} & \multirow[t]{2}{*}{$\begin{array}{l}\text { Nilai } \\
\text { Min-Max }\end{array}$} & \multirow[t]{2}{*}{$\begin{array}{l}\text { Std. } \\
\text { Deviasi }\end{array}$} & \multirow{2}{*}{$\begin{array}{l}\text { Rata- } \\
\text { rata } \\
\text { (ppm) }\end{array}$} & \multirow[t]{2}{*}{$\begin{array}{c}\text { Standar } \\
\text { (ppm) }\end{array}$} \\
\hline & 1 & 2 & 3 & 4 & 5 & 6 & & & & \\
\hline $\begin{array}{c}\text { Pretes } \\
\mathrm{t}\end{array}$ & 4.17 & - & - & - & - & - & - & - & - & \multirow{5}{*}{$\begin{array}{c}\text { Maks. } \\
1\end{array}$} \\
\hline 0 & 3.95 & 4.1 & 4.19 & 3.98 & 4.14 & 4.2 & $3.95-4.19$ & 0.11 & 4.09 & \\
\hline 2 & 2.61 & 2.57 & 2.55 & 2.6 & 2.57 & 2.59 & $2.55-2.59$ & 0.022 & 2.58 & \\
\hline 6 & 1.04 & 1.01 & 1.04 & 1.02 & 1.06 & 1.04 & $1.01-1.06$ & 0.017 & 1.04 & \\
\hline 10 & 0.11 & 0.11 & 0.09 & 0.07 & 0.1 & 0.09 & $0.07-0.11$ & 0.015 & 0.10 & \\
\hline
\end{tabular}


Tabel 2 menunjukkan bahwa adanya perbedaan kadar besi (Fe) pada masing masing dosis penambahan penambahan bioadsorben kulit kedelai. Penambahan bioadsorben kulit kedelai dengan variasi dosis memiliki pengaruh terhadap kandungan besi ( $\mathrm{Fe}$ ) pada air baku. Berdasarkan Hasil analisis Annova Satu Arah (One Way Annova) dapat diketahui bahwa nilai kebenaran atau nilai dari Sig. $(\rho)$ suatu hipotesis adalah 0.000 . Nilai ( $\rho$-value) $0.000<$ a 0.05 , yang berarti minimal ada satu pasang dosis yang memiliki rata-rata kadar besi $(\mathrm{Fe})$ yang berbeda.
Pada uji analisis LSD (Least Square Differences) menunjukkan hasil perbedaan rata rata kadar besi (Fe) dari penambahan bioadsorben $2 \mathrm{gr} / \mathrm{l}$ dan 6 $\mathrm{gr} / \mathrm{l}$ sebesar $1.54 \mathrm{ppm} ; 2 \mathrm{gr} / \mathrm{l}$ dan $10 \mathrm{gr} / \mathrm{l}$ sebesar $2.48 \mathrm{ppm}$; serta $6 \mathrm{gr} / \mathrm{l}$ dan 10 $\mathrm{gr} / \mathrm{l}$ sebesar $0.94 \mathrm{ppm}$. Semua nilai Sig. ( $\rho$ ) suatu hipotesis adalah 0.000 , ini berarti semua pasangan memiliki ratarata kadar besi (Fe) yang berbeda. Pasangan dari dosis $2 \mathrm{gr} / \mathrm{l}$ dan $10 \mathrm{gr} / \mathrm{l}$ menjadi pasangan yang memiliki beda rata-rata paling nyata pada penelitian ini dengan nilai perbedaan rata-rata sebesar $2.48 \mathrm{ppm}$.

\section{Pengukuran perbedaan rata-rata penurunan kadar besi (Fe) pada air baku sebelum dan sesudah penambahan bioadsorben kulit kedelai.}

\section{Tabel 3}

PENURUNAN KADAR BESI

\begin{tabular}{ccc}
\hline Dosis & $\begin{array}{c}\text { Rata rata penurunan } \\
\text { kadar besi (ppm) }\end{array}$ & $\begin{array}{c}\text { Presentase } \\
\text { penurunan }\end{array}$ \\
\hline $2 \mathrm{gr} / \mathrm{l}$ & 1.59 & $38 \%$ \\
\hline $6 \mathrm{gr} / \mathrm{l}$ & 3.14 & $75 \%$ \\
\hline $10 \mathrm{gr} / \mathrm{l}$ & 4.08 & $98 \%$ \\
\hline
\end{tabular}

Berdasarkan Tabel 4 mengenai penurunan kadar besi ( $\mathrm{Fe})$ setelah dilakukan penambahan bioadsorben dari kulit kedelai menunjukkan bahwa semakin tinggi dosis penambahan bioadsorben kulit kedelai, presentasi penurunan kadar besi ( $\mathrm{Fe}$ ) juga semakin tinggi pula. Hal tersebut didukung dengan hasil analisis Annova Satu Arah (One Way Annova) diketahui bahwa nilai kebenaran atau nilai dari Sig. ( $\rho$ ) suatu hipotesis adalah 0.000 . Nilai ( $\rho$-value) $0.000<a 0.05$, yang berarti minimal ada satu pasang dosis yang memiliki rata-rata selisih penurunan kadar besi (Fe) yang berbeda. Dari hasil analisis probit menunjukkan penurunan kadar besi setelah ditambahkan bioadsorben kulit kedelai dengan dosis $3.349 \mathrm{gr} / \mathrm{l}$ pada air baku, dapat menurunkan kadar besi (Fe) sebesar $80 \%$ (optimum) yang ada pada air baku tersebut.

\section{PEMBAHASAN}

Faktor yang mempengaruhi kadar air dari arang aktif adalah proses dehidrasi, dan karbonasi. Pada pembuatan bioadsorben kulit kedelai telah melalui proses dehidrasi dengan menjemur dibawah sinar matahari serta mengoven selama 1 jam dengan suhu $105^{\circ} \mathrm{C}$, kemudian di karbonisasi dengan tanur dengan suhu $275^{\circ} \mathrm{C}$. Dehidrasi dan karbonisasi menyebabkan berkurangnya kadar air yang terkandung dalam bahan. Kadar air yang ada telah berkurang dikarenakan pada proses pengovenan, air mengalami perubahan fase menjadi gas pada saat telah mencapai titik didihnya, yakni pada suhu $100^{\circ} \mathrm{C}$ (Vinsiah, Suharman dan Desi, 2014). Kemudian dengan kadar air yang minim dilakukan proses karbonisasi dengan suhu $275^{\circ} \mathrm{C}$ yang mengakibatkan berkurangnya kadar air hingga dibawah standar yang berlaku.

Tingginya kadar abu menunjukkan adanya proses oksidasi lebih lanjut (Abdi, et al 2015), abu berlebih yang terbentuk menyumbat pori pori dari bioadsorben, sehingga mengurangi kemampuan bioadsorben dalam menurunkan besi (Fe) dalam air. Aktivator $\mathrm{KOH}$ bekerja maksimal dalam kondisi operasi suhu $700-800^{\circ} \mathrm{C}$ dengan 
lama waktu tingggal 1 jam (Esterlita and Herlina 2015) sedangkan suhu yang digunakan pada penelitian ini adalah $275{ }^{\circ} \mathrm{C}$ Suhu yang bertujuan untuk meminimalisir resiko kerusakan hasil dari proses karbonisasi, sehingga kerja dari $\mathrm{KOH}$ sebagai agen aktivator yang menjaga agar sampel tidak terbakar, kinerja $\mathrm{KOH}$ dalam bereaksi dengan kandungan mineral dalam bahan baku kurang maksimal sehingga kadar abu melebihi persyaratan SNI 0637301995 (Maksimal 10 \%). Bagi peneliti selanjutnya diharapkan dapat meningkatkan parameter kadar abu bioadsorben kulit kedelai dengan cara meningkatkan kualitas arang aktif melalui peningkatan suhu karbonisasi dan menggunakan aktivator lain untuk membuat bioadsorben kulit kedelai.

Penambahan bioadsorben kulit kedelai dengan variasi dosis memiliki pengaruh terhadap kandungan besi $(\mathrm{Fe})$ pada air baku. Bioadsorben yang bersifat adsorb, dapat mengurangi kadar besi (Fe) dalam air baku. Polutan polutan diadsorb dengan bioadsorben sehingga polutan pada air baku berkurang kadarnya dan pada dosis penambahan bioadsorben kulit kedelai $10 \mathrm{gr} / \mathrm{l}$ dapat membuat kadar besi (Fe) memenuhi standar permenkes no 32 tahun. Perbedaan kadar besi pada masing-masing perlakuan menunjukkan bahwa proses adsorbsi yang terjadi dapat menurunkan kadar besi yang ada, hal ini juga dipertegas dengan hasil replikasi dari kadar besi pada dosis 0 $\mathrm{gr} / \mathrm{l}$ (kontrol) yang memiliki standar deviasi 0.11 yang berarti variansi kadar besi (Fe) kecil, faktor faktor yang dikontrol tidak mempengaruhi secara signifikan dan yang mempengaruhi penurunan kadar besi ( $\mathrm{Fe}$ ) pada air baku secara signifikan adalah penambahan bioadsorben kulit kedelai.

Hasil penurunan kadar besi (Fe) menunjukkan bahwa telah terjadi proses adsorbsi yang dilakukan oleh bioadsorben dari kulit kacang kedelai. Prinsip penurunan kadar besi dalam air adalah proses oksidasi dan pengendapan. Adapun prosesnya adalah besi dalam bentuk ferro dioksidasi terlebih dahulu menjadi bentuk ferri, kemudian pengendapan dengan membentuk endapan ferrhidroksida. Proses ini mudah terjadi pada kondisi $\mathrm{pH}$ + 7 dimana keluarutannya minimum.

Persamaan reaksi:

$4 \mathrm{Fe}(\mathrm{OH})_{2}+2 \mathrm{H}_{2} \mathrm{O}+\mathrm{O}_{2} \leftrightarrow 4 \mathrm{Fe}(\mathrm{OH})_{3}$

Jadi penurunan kadar besi dalam

air pada hakikatnya mengubah dari bentuk yang larut dalam air menjadi yang tidak terlarut dalam air. Oleh karena itu hasil dari reaksi oksidasi ini selalu menghasilkan endapan (Joko 2010). Proses pengolahan air dengan karbon aktif merupakan proses adsoprsi secara fisika (physical adsorbtion) yaitu proses terakumulasinya molekul-molekul adsorbate (zat yang akan diadsorpsi) dalam air (misalnya zat organik dll.) ke permukaan karbon aktif karena adanya gaya tarik menarik antara molekul karbon aktif dengan molekul molekul adsorbate yang ada dalam air (gaya Van der Walls) (Said 2017).

Pengaplikasian bioadsorben kulit kedelai selain menggunakan pengadukan dan pencampuran, juga bisa diaplikasikan dengan metode filtrasi untuk menurunkan polutan yang diinginkan untuk mengetahui nilai penurunan polutan tersebut perlu dilakukan penelitian lebih lanjut tentang bioadsorben kulit kedelai yang diaplikasikan dengan metode filtrasi.

\section{KESIMPULAN}

Bioadsorben dapat dibuat dari bahan dasar kulit kedelai (Glycine max) yang dapat menurunkan kadar besi (Fe) dalam air. Kadar air dari Bioadsorben kulit kedelai $4.16 \%$ dan kadar abu yang diperoleh dari bioadsorben kulit kedelai adalah (17.22\%).

Ada perbedaan baik dalam rata-rata kadar besi (Fe) maupun rata-rata penurunan kadar besi (Fe) pada air sebelum dan sesudah dilakukan penambahan bioadsorben kulit kedelai (Glycine max) dengan variasi dosis $0 \mathrm{gr} / \mathrm{l}$, $2 \mathrm{gr} / \mathrm{l}, 6 \mathrm{gr} / \mathrm{l}$ dan $10 \mathrm{gr} / \mathrm{l}$. Dosis penambahan yang optimum untuk menurunkan kadar besi (Fe) dalam air adalah 3,205 $\mathrm{gr} / \mathrm{l}$ dengan presentase penurunan sebanyak $80 \%$. 


\section{SARAN}

Diperlukan penelitian lebih lanjut untuk meningkatkan kualitas arang aktif melalui peningkatan suhu karbonisasi $700-800^{\circ} \mathrm{C}$ untuk aktivator $\mathrm{KOH}$ dan menggunakan aktivator lain seperti $\left(\mathrm{NaOH}, \mathrm{H}_{2} \mathrm{SO}_{4}\right.$ dll) untuk membuat bioadsorben kulit kedelai serta menggunakan metode filtrasi untuk pengaplikasian bioadsorben kulit kedelai untuk mengurangi kekeruhan yang terjadi pada air.

\section{DAFTAR PUSTAKA}

Abdi, Chairul, Riza Miftahul Khair, and M. Wahyuddin Saputra. 2015. "Pemanfaatan Limbah Kulit Pisang Kepok ( Musa Acuminate L ) Sebagai Karbon Aktif Untuk Pengolahan Air Sumur Kota Banjarbaru: Fe Dan Mn." Jurnal Teknik Lingkungan 1(1):8-15.

Arief, Lahar. 2016. Pengolahan Limbah Industri Dasar - Dasar Pengetahuan Dan Aplikasi Di Tempat Kerja. Yogyakarta: Nuha Media.

BSN. 1995. "SNI 06-3730-1995 Tentang Arang Aktif Teknis."

Duta.co. 2018. "Pemprov Perluas Lahan Tanam Kedelai Di Jawa Timur." Duta.

Esterlita, Marina and Netti Herlina. 2015. "Pengaruh Penambahan Aktivator $\mathrm{ZnCl}$, $\mathrm{KOH}$, Dan H3PO4 Dalam Pembuatan Karbon Aktif Dari Pelepah Aren (Arenga Pinnata)." Jurnal Teknik Kimia Usu.
Ghafarunnisa, Desyana, Abdul Rauf, Bantar Tyas, Sukmawati Rukmana, Mahasiswa Magister, Teknik Pertambangan, and U. P. N. Veteran Yogyakarta. 2017. "Pemanfaatan Batubara Menjadi Karbon Aktif Dengan Proses Karbonisasi Dan Aktivasi Menggunakan Reagen Asam Fosfat (H3PO4) Dan Ammonium Bikarbonat ( NH4HCO3)."

Haidah, N. ur and Irmawartini. 2018. "Metodologi Penelitian."

Joko, Tri. 2010. Unit Produksi Dalam Penyediaan Air Minum. Yogyakarta: Graha Ilmu.

Kementerian Kesehatan RI. 2017. Peraturan Menteri Kesehatan Republik Indonesia Nomor 32 Tahun 2017 Tentang Standar Baku Mutu Kesehatan Lingkungan Dan Persyaratan Kesehatan Air Untuk Keperluan Higiene Sanitasi, Kolam Renang, Solus Per Aqua, Dan Pemandian Umum. Jakarta.

Perda Jatim, Pemerintah Jawa Timur. 2008. "PERDA JATIM No 2 Th 2008." Perda Jatim No 02 Th 2008 1-34.

Pojokpitu.com. 2018. "Minus Kedelai, Jatim Terpaksa Impor 48 Ribu Ton." Pojokpitu.

Said, Nusa. 2017. Teknologi Pengolahan Air Limbah Teori Dan Aplikasi. Jakarta: Erlangga.

Vinsiah, Renanda., Suharman Andi dan Desi. 2014. Pembuatan Karbon Aktif dari Cangkang Kulit Buah Karet (Hevea brasilliensis).Program Studi Pendidikan Kimia FKIP Universitas Sriwijaya.Vol. 1, No 2. 